\section{JURNAL ABDIMAS

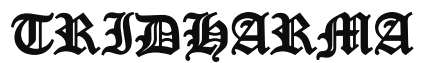

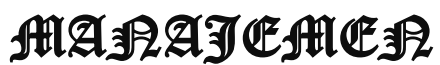

P-ISSN 2615-6849, E-ISSN 2716-070X

Jurnal ABDIMAS Vol. 2,No.3, Agustus 2021,Hal(62-74)

@ Prodi Manajemen Fakultas Ekonomi Universitas Pamulang

Email: abdimasjurnal.unpam@ gmail.com Telp: (021) 741-2566

\title{
PENYULUHAN PERAN ORGANISASI KARANG TARUNA DALAM PELATIHAN PENINGKATAN KESEHATAN DAN PERENCANAAN KEUANGAN DI MASA PANDEMI
}

\author{
Intan Sari Budhiarjo, Fathan Arif, Susilawati, Arief Rahman Akbar, Rizka Putri Anggraeni \\ Dosen Prodi Manajemen Fakultas Ekonomi Universitas Pamulang \\ Email : dosen02128@unpam.ac.id, dosen02154@unpam.ac.id,dosen02625@unpam.ac.id, \\ dosen02515@unpam.ac.id, dosen02520@unpam.ac.id
}

\begin{abstract}
ABSTRAK
Tujuan dari kegiatan Pengabdian Kepada Masyarakat ini adalah untuk melaksanakan salah satu Tri Dharma Perguruan Tinggi. Selain itu, melalui kegiatan Pengabdian Kepada Masyarakat ini, keberadaan perguruan tinggi diharapkan dapat memberikan kontribusi besar kepada pengembangan dan penerapan keilmuan dalam masyarakat.

Metode kegiatan yang digunakan adalah tim pelaksana mengunjungi Karang Taruna yang beralamat di Jalan Pondok Salak RT.005/RW.022, Kelurahan Pondok Benda, Kecamatan Pamulang Kota Tangerang Selatan dan memberikan pelatihan mulai tanggal 03 - 05 April 2021. Pelatihan ini bertujuan agar Karang Taruna yang rata-rata masih berusia remaja memahami pentingnya peran organisasi Karang Taruna atau pelatihan peningkatan kesehatan dan perencanaan keuangan untuk meraih tujuan-tujuan keuangan yang lebih besar dan bisa menerapkan perencanaan keuangan tersebut dalam kehidupannya mulai sekarang, terutama sebagai bekal dalam menghadapi kesulitan ekonomi seperti di masa pandemi saat ini.

Hasil kegiatan Pengabdian Kepada Masyarakat ini adalah bertambahnya keilmuan dan keterampilan remaja Karang Taruna, khususnya di bidang peningkatan kesehatan dan perencanaan keuangan yaitu pelatihan yang akan menjadi bekal mereka dalam mengelola kesehatan dan keuangan, baik di masa normal maupun di masa kesulitan ekonomi seperti sekarang. Ilmu yang didapatkan pada kegiatan Pengabdian Kepada Masyarakat ini diharapkan mampu memberikan semangat dalam menyampaikan pengetahuan dan memberikan motivasi serta berkontribusi bagi generasi muda, baik di lingkungan sekolah, kampus maupun masyarakat.
\end{abstract}

\section{Kata kunci : Peningkatan Kesehatan, Perencanaan Keuangan, Masa Pandemi}

\section{ABSTRACT}

The purpose of this Community Service activity is to carry out one of the Tri Dharma of Higher Education. In addition, through this Community Service activity, the existence of universities is expected to make a major contribution to the development and application of science in the community.

The method of activity used is the implementation team to visit Karang Taruna which is located at Jalan Pondok Salak RT.005/RW.022, Pondok Benda Village, Pamulang District, South Tangerang City and provide training from 03 - 05 April 2021. This training aims to make Karang Taruna who is still in his teens understand the importance of the role of Karang Taruna organization or training in improving health and financial planning to achieve greater financial goals and be able to implement such financial planning in his life from now on, especially as a provision in the face of economic difficulties such as in the current pandemic.

The result of this Community Service activity is the increase in the knowledge and skills of Karang Taruna youth, especially in the field of health improvement and financial planning, 


\section{JURNAL ABDIMAS

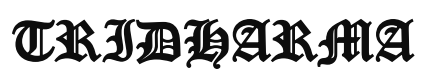 AtA}

namely training that will be their provision in managing health and finance, both in normal times and in times of economic difficulties such as today. The knowledge obtained in this Community Service activity is expected to provide encouragement in conveying knowledge and providing motivation and contributing to the younger generation, both in the school environment, campus and community.

\section{Keywords: Health Improvement, Financial Plannin, Pandemic Period}

\section{PENDAHULUAN}

Karang Taruna adalah organisasi kepemudaan di Indonesia. Karang Taruna merupakan wadah pengembangan generasi muda nonpartisan, yang tumbuh atas dasar kesadaran dan rasa tanggung jawab sosial dari, oleh dan untuk masyarakat khususnya generasi muda di wilayah Desa/ Kelurahan atau komunitas sosial sederajat, yang terutama bergerak dibidang kesejahteraan sosial. Sebagai organisasi sosial kepemudaan Karang Taruna merupakan wadah pembinaan dan pengembangan serta pemberdayaan dalam upaya mengembangkan kegiatan ekonomi produktif dengan pendayagunaan semua potensi yang tersedia di lingkungan baik sumber daya manusia maupun sumber daya alam yang telah ada.

Sebagai organisasi kepemudaan, Karang Taruna berpedoman pada Pedoman Dasar dan Pedoman Rumah Tangga di mana telah pula diatur tentang struktur pengurus dan masa jabatan di masing-masing wilayah mulai dari Desa/ Kelurahan sampai pada tingkat Nasional. Semua ini wujud dari pada regenerasi organisasi demi kelanjutan organisasi serta pembinaan anggota Karang Taruna baik dimasa sekarang maupun masa yang akan datang. Karang Taruna beranggotakan pemuda dan pemudi (dalam $\mathrm{AD} / \mathrm{ART}$ nya diatur keanggotaannya mulai dari pemuda/i berusia mulai dari $11-45$ tahun) dan batasan sebagai Pengurus adalah berusia mulai 17 - 35 tahun.

Karang Taruna didirikan dengan tujuan memberikan pembinaan dan pemberdayaan kepada para remaja, misalnya dalam bidang keorganisasian, ekonomi, olahraga, ketrampilan, advokasi, keagamaan dan kesenian.
Salah satu persoalan yang dihadapi oleh kebanyakan remaja Karang Taruna adalah kurangnya kesadaran dalam meningkatkan kesehatan dan mengatur keuangannya. Hal ini berimbas pada para remaja tersebut menjadi sering terlihat berkerumun dengan remaja lainnya, boros dan berperilaku konsumtif demi mengikuti gaya hidupnya dan membuat mereka menjadi remaja yang tidak bertanggungjawab. Pemborosan dan perilaku konsumtif tersebut bisa diminimalkan dengan mengajarkan perencanaan keuangan kepada mereka. Melakukan peningkatan kesehatan dan perencaaan keuangan bukan hanya bisa dilakukan oleh orang yang sedang sakit dan sudah berkeluarga, tetapi harus diterapkan untuk dilakukan oleh para remaja. Remaja berasal dari bahasa Latin adolescare yang artinya tumbuh atau tumbuh untuk mencapai kematangan. Masa remaja adalah masa transisi dalam rentang kehidupan manusia, menghubungkan masa kanak-kanak dan dewasa (Santrock, 2003). Pada 1974, WHO (World Health Organization) memberikan definisi tentang remaja yang lebih bersifat kontekstual. Dari sisi biologis, remaja adalah individu yang berkembang dari saat pertama kali menunjukkan tanda-tanda seksual sekundernya sampai mencapai kematangan seksual. Dari sisi psikologis, remaja adalah individu yang mengalami perkembangan psikologis dan pola identifikasi dari kanakkanak menjadi dewasa. Dari sisi sosial ekonomi, remaja adalah individu yang mengalami peralihan dari ketergantungan sosial-ekonomi yang penuh kepada keadaan yang relatif mandiri.

Menurut Papalia \& Olds (dalam Jahja, 2012), masa remaja adalah masa transisi perkembangan antara masa kanak- 


\section{JURNAL ABDIMAS

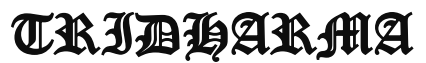

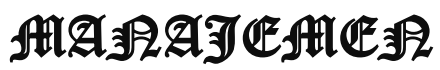

kanak dan dewasa yang pada umumnya dimulai pada usia 12 atau 13 tahun dan berakhir pada usia akhir belasan tahun atau awal dua puluhan tahun. Batasan usia remaja menurut WHO adalah 12 sampai 24 tahun. Sementara menurut Menteri Kesehatan RI tahun 2010, batas usia remaja antara 10 sampai 19 tahun dan belum menikah (Widyastuti dkk, 2009).

Masa remaja merupakan masa pencarian identitas dirinya. Pada masa ini, peran orang tua dan lingkungan sangat penting agar remaja mengenal dirinya, beradaptasi dengan lingkungannya dan mampu menghadapi tantangan kehidupan.

Kurangnya peran orang tua dan lingkungan dalam masa pertumbuhan remaja, membuat mereka menjalani gaya hidup yang tidak terarah bahkan menyimpang. Gaya hidup seorang remaja saat ini sangat berkaitan erat dengan semakin berkembangnya teknologi informasi dan komunikasi. Dengan fasilitas teknologi dan informasi yang mereka miliki, mereka bebas mencari dan menentukan gaya hidup yang mereka mau.

Gaya hidup remaja saat ini cenderung konsumtif dan boros. Mereka membeli barang yang diinginkan, bukan barang yang dibutuhkan, karena begitu derasnya pengaruh lingkungan dan iklan produk. Uang saku yang diberikan orang tua selalu habis bahkan kurang untuk memenuhi gaya hidupnya.

Untuk membuka wacana pengetahuan tentang pentingnya peran mereka dalam peningkatan kesehatan dan pelaksanaan perencanaan keuangan (financial planning) di kalangan remaja, terutama di masa pandemi seperti ini, kami tim pelaksana kegiatan PKM (Pengabdian Kepada Masyarakat) Prodi Manajemen Fakultas Ekonomi Universitas Pamulang akan bekerja sama dengan Organisasi Karang Taruna untuk mensosialisasikan hal ini kepada para remaja Karang Taruna. Tema yang kami ambil adalah "Penyuluhan Peran Organisasi Karang Taruna Dalam Pelatihan Peningkatan Kesehatan Dan Perencanaan Keuangan Di Masa Pandemi."

\section{RUMUSAN MASALAH}

Berdasarkan analisis situasi permasalahan yang telah diutarakan diatas kami berinisiatif untuk membentuk pengabdian masyarakan bagi Ketua dan segenap para anggota Karang Taruna 022 Kelurahan Pondok Benda, Kecamatan Pamulang Kota Tangerang Selatan melalui progam dengan Cara Penyuluhan peran Karang Taruna dalam pelatihan peningkatan kesehatan dan perencanaan keuangan di masa pandemi agar mereka memiliki pandangan yang baik bagaimana upaya pencegahan dan penanggulangan pandemi Covid-19 dan mengelola keuangan dengan baik.

Berdasarkan analisis situasi permasalahan di atas, maka tersusunlah rumusan masalah dalam kegiatan PKM ini, sebagai berikut : Bagaimanakah cara memberikan pelatihan kesehatan dan perencanaan keuangan di masa pandemi dengan baik dan benar?

\section{TUJUAN KEGIATAN}

Adapun tujuan yang hendak dicapai melalui kegiatan pengabdian kepada masyarakat, sebagai berikut :

a. Memberikan Penyuluhan peran Karang Taruna dalam pelatihan peningkatan kesehatan yang baik dan benar di lingkungan RW.022 Kelurahan Pondok Benda dan masyarakat sekitar.

b. Membuka pemikiran dan pandangan dalam upaya penanggulangan dampak pandemi melalui tata cara perencanaan keuangan agar lebih teratur dan terencana.

c. Mempengaruhi seluruh pengurus karang taruna 022 dalam membentuk suatu perilaku dan memotori gerakan sosial yang bertujuan menanggulangi pandemi Covid-19 dan mengatasi keuangan yang lebih baik lagi.

\section{TINJAUAN PUSTAKA}

\section{Pelatihan Peningkatan Kesehatan}

Menurut Mondy, (2008: 210), pelatihan merupakan serangkaian aktivitas yang dirancang guna memberi pengetahuan dan keterampilan yang dibutuhkan para 


\section{JURNAL ABDIMAS

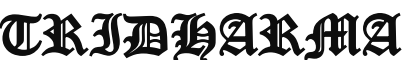

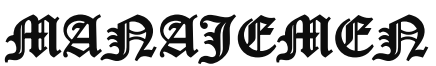

pembelajar untuk dapat melaksanakan pekerjaan mereka pada saat ini. Sedangkan Dessler (2008: 280), menyatakan bahwa pelatihan dimaksudkan untuk memberikan keterampilan yang dibutuhkan bagi karyawan baru maupun karyawan yang sudah ada dalam melakukan pekerjaannya.

Menurut (Robert.H.Brook, 2017:585), kesehatan adalah sebuah sumber daya yang dimiliki semua manusia dan bukan merupakan suatu tujuan hidup yang perlu dicapai. Kesehatan tidak terfokus kepada fisik yang bugar tetapi meliputi jiwa yang sehat di mana individu dapat bersikap toleran dan dapat menerima perbedaan.

Latihan fisik merupakan serangkaian kegiatan yang dilakukan dengan tujuan meningkatkan kebugaran tubuh ataupun memelihara kebugaran tubuh. Latihan fisik dapat dilakukan untuk mencapai beberapa tujuan tertentu meliputi memperkuat otot dan kerja jantung, penurunan berat badan, melatih kemampuan atletik, ataupun untuk memperindah bentuk tubuh. Seiring dengan semakin teraturnya latihan fisik dilakukan, maka kekebalan tubuh pun semakin meningkat dan mengurangi resiko terjadinya penyakit-penyakit kronis terutama terkait dengan jantung dan ginjal seperti cardiovascular, Hipertensi, dan Diabetes tipe 2 (Majid Ezzati, 2005:48).

Peningkatan kesehatan merupakan bagian dari pembangunan nasional yang bertujuan meningkatkan kesadaran, kemauan dan kemampuan hidup sehat bagi setiap orang agar terwujud derajat kesehatan masyarakat yang setinggi-tingginya. Pembangunan kesehatan tersebut merupakan upaya seluruh potensi bangsa Indonesia, baik masyarakat, swasta maupun pemerintah.

Peningkatan kesehatan harus diimbangi dengan intervensi perilaku yang memungkinkan masyarakat lebih sadar, mau dan mampu melakukan hidup sehat sebagai prasyarat pembangunan yang berkelanjutan (sustainable development). Untuk menjadikan masyarakat mampu hidup sehat, masyarakat harus dibekali dengan pengetahuan tentang cara-cara hidup sehat.
Tujuan Pelatihan Peningkatan Kesehatan Pelaksanaan Pelatihan Peningkatan Kesehatan bertujuan untuk meningkatkan kesadaran, kemauan dan kemampuan hidup sehat bagi setiap orang agar terwujud derajat kesehatan masyarakat yang optimal ditandai hidup dengan perilaku dan dalam lingkungan sehat, memiliki kemampuan untuk menjangkau pelayanan kesehatan yang bermutu secara adil dan merata, serta memiliki derajat kesehatan yang optimal juga.

Adapun tujuan utama dari peningkatan kesehatan yaitu peningkatan kemampuan masyarakat untuk menolong dirinya sendiri dalam bidang kesehatan, perbaikan mutu lingkungan hidup yang dapat menjamin kesehatan, peningkatan status gizi masyarakat, pengurangan kesakitan (morbiditas) dan kematian (mortalitas) dan pengembangan keluarga sehat sejahtera.

\section{Manajemen Peningkatan Kesehatan Untuk Mencegah Penyakit \\ Untuk mewujudkan peningkatan} kesehatan yang baik dan benar ditiap tatanan diperlukan pengelolaan manajemen peningkatan kesehatan untuk mencegah penyakit melalui tahap-tahap sebagai berikut:

a) Peningkatan kesehatan merupakan segala bentuk upaya yang dilakukan oleh Karang Taruna untuk mengoptimalkan kesehatan melalui kegiatan penyuluhan, penyebarluasan informasi, atau kegiatan lain untuk menunjang tercapainya hidup sehat.

b) Pencegahan penyakit merupakan segala bentuk upaya yang dilakukan oleh Karang Taruna untuk menghindari atau mengurangi risiko, masalah, dan dampak buruk akibat penyakit baik penyakit menular maupun tidak menular.

c) Karang Taruna bekerja sama dengan aparat terkait untuk menjamin dan menyediakan fasilitas untuk kelangsungan upaya peningkatan kesehatan dan pencegahan penyakit.

d) Ketentuan lebih lanjut tentang upaya peningkatan kesehatan dan pencegahan 


\section{JURNAL ABDIMAS

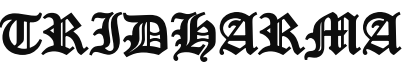 AIA:}

penyakit berpedoman pada peraturan perundang-undangan.

\section{Manfaat Peningkatan Kesehatan}

Menggunakan masker sangat efektif dalam pencegahan virus corona. Selain itu, cuci tangan juga sama pentingnya dengan memakai masker. Untuk saat ini pemerintah sangat gencar untuk mengkampanyekan pemakaian masker, mulai dari sanksi sosial hingga materi.

Masker juga dikenal dengan alat pelindung diri. Sebagai alat pelindung diri, masker dirancang untuk memberikan perlindungan kepada pemakainya dan bukan sebaliknya menjadi sarana transmisi atau penularan karena penggunaan yang salah.

Kesehatan merupakan aspek penting yang dapat mempengaruhi quality of life setiap individu. Salah satu cara yang efektif untuk menjaga kesehatan tubuh adalah menjaga kebersihan, salah satunya adalah kebersihan tangan, karena tangan adalah salah satu anggota tubuh yang sangat berperan penting dalam beraktivitas seharihari. Masyarakat tidak sadar bahwa pada saat beraktivitas tangan sering kali terkontaminasi dengan mikroorganisme karena tangan menjadi perantara masuknya mikroba ke saluran cerna. Mencuci tangan merupakan langkah awal untuk menghindari berbagai jenis kuman penyebab penyakit infeksi tetapi langkah ini sering kali diabaikan ataupun terlewatkan begitu saja.

Mencuci tangan dengan sabun boleh jadi cara efektif melindungi diri dari serangan penyakit menular. Namun, apabila cuci tangan tidak memungkinkan, kita bisa menggunakan gel atau cairan pembersih tangan (hand sanitizer) dengan kadar alkohol setidaknya 60 persen. Menurut riset, hand sanitizer dengan kadar alkohol 60-95 persen paling efektif mengurangi sejumlah mikroba di tangan.

Banyak manfaat yang diperoleh dari peningktan kesehatan pada tubuh, salah satunya dengan berolahraga. Olahraga membantu hidup Anda lebih sehat dan bugar. Dilansir dari laman Dokter Sehat, olahraga adalah gerakan oleh tubuh yang memberikan efek pada tubuh secara keseluruhan. Olahraga melatih otot-otot, membantu sirkulasi darah dan oksigen dalam tubuh menjadi lancar.

Olahraga merupakan jenis kegiatan fisik yang baik untuk pikiran, tubuh, serta jiwa. Melakukan olahraga mampu menjaga kebugaran, kesejahteraan mental, serta interaksi sosial. Olahraga secara rutin merupakan satu di antara langkah untuk mengantisipasi pencegahan memiliki risiko penyakit berbahaya dalam tubuh. Kegiatan ini bisa dilakukan oleh siapa saja dan semua umur.

Daniel Landers, profesor dari Arizona State University menyatakan olahraga dikatakan sebagai obat alami yang kemudian menginspirasi terciptanya terapi olahraga (sport therapy).

Adapun manfaat dari pelatihan peningkatan kesahatan yaitu terhindar dari berbagai macam penyakit, memiliki lebih banyak energi, berat badan terjaga, hidup lebih teratur, menjaga produktifitas, bersikap lebih positif, menjaga kesehatan mental, kulit terlihat lebih fresh, meningkatkan kepercayaan diri, dan dapat menikmati hidup secara optimal.

\section{Perencanaan Keuangan}

Perencanaan keuangan adalah suatu ilmu yang menempatkan kajian tentangkeuangan dengan menempatkan berbagai atribut keuangan secara terkonsep dan sistematis baik secara jangka pendek maupun jangka panjang. Dalam konsep jangka pendek biasanyasatu atau dua saja. Sedangkan jangka panjang beberapa pakar menyatakan jangkawaktunya berkisar dua hingga lima tahun ke depan, bahkan beberapa pakar jugamenyebutkan bahwa jangka waktunya bisa lebih dari 5 tahun. Ideide ini tidak hanya untuk individu tetapi juga harus dilakukan untuk organisasi mana pun jika tetap bertahan dan mengelola uangnya dengan baik. Perencanaan keuangan untuk suatu organisasi adalah proses menentukan bagaimana mereka akan mendanai kegiatan mereka untuk memastikan mereka memenuhi tujuan dan sasaran strategis mereka. 


\section{JURNAL ABDIMAS

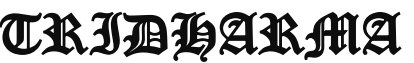 AtA:}

P-ISSN 2615-6849, E-ISSN 2716-070X

Jurnal ABDIMAS Vol. 2,No.3, Agustus 2021,Hal(62-74)

@ Prodi Manajemen Fakultas Ekonomi Universitas Pamulang

Email: abdimasjurnal.unpam@gmail.com Telp: (021) 741-2566
Menurut Senduk (2001) perencanaan keuangan adalah proses merencanakan tujuan-tujuan keuangan jangka pendek maupun jangka panjang. Yang dimaksud dengan tujuan keuangan itu adalah keinginan keuangan yang ingin direalisasikan Salah satu perencana keuangan seperti Gozali (2002) mendefinisikan rencana keuangan sebagai "Sebuah strategi yang apabila dijalankan bisa membantu anda mencapai tujuan keuangan dimasa datang“. Sedangkan Dorimulu (2003) dalam artikelnya, menyatakan bahwa perencanaan keuangan atau Financial planning merupakan "Proses mencapai tujuan hidup yakni masa depan yang sejahtera dan bahagia lewat penataan keuangan “.

Dalam rencana keuangan, kegiatan disesuaikan dengan sumber daya, peralatan, dan bahan yang dibutuhkan untuk mencapai dan kerangka waktu juga tercantum. Perencanaan keuangan menegaskan kepada bisnis bahwa apa yang telah ditetapkan untuk dicapai adalah mungkin untuk membentuk sudut pandang keuangan. Ini ditetapkan di muka, sesuai dengan cadangan kas Anda dan pendapatan yang diharapkan di masa depan, berapa banyak untuk dibelanjakan dan untuk apa belanja itu.

Sumber daya keuangan Karang Taruna Adalah segala potensi strategis yang dapat diarahkan menjadi sumber-sumber keuangan organisasi Karang Taruna baik yang bersifat internal maupun eksternal. Sumberdaya Internal, yang terdiri dari Iuran anggota aktif, keuntungan usaha (baik usaha dalam bentuk koperasi maupun usaha ekonomis produktif yang dikelola sendiri oleh pengurus/anggota Karang Taruna) dan sumbangan pengurus dan/atau anggota aktif Karang Taruna baik yang bersifat terikat maupun tidak terikat. Sumberdaya eksternal, yang terdiri dari sumbangan donasi pihak luar baik yang bersifat terikat maupun tidak terikat, keuntungan dari hasil kerjasama atau usaha dengan mitra yang diikat berdasarkan perjanjian kerjasama usaha tertentuk, keuntungan sponsorship dari kegiatan tertentu yang bekerjasama dengan pihak sponsor tertentu, dengan besaran jumlah yang diatur tersendiri dan subsidi dari pihak pemerintah berdasarkan pos anggaran tertentu baik untuk kegiatan kesejahteraan sosial, maupun untuk kegiatan kepemudaan umumnya.

Pada dasarnya upaya penggalian sumberdaya keuangan organisasi Karang Taruna diselenggarakan dalam sebuah perencanaan bersama dengan pemegang otoritas keuangan organisasi Karang Taruna yakni Ketua/Ketua Umum, Sekretaris/ Sekretaris Umum, dan Bendahara/Bendahara Umum. Perencanaan keuangan organisasi terproyeksi pada junlah keseluruhan kebutuhan berdasarkan pos pembelanjaan utama/penting yang telah ditetapkan bersama dalam rangka menjalankan roda organisasi dan programprogram kerjanya. Perencanaan keuangan organisasi seperti dimaksud pada ayat 2 pasal ini diselenggarakan berdasarkan prinsip berimbang antara kekutatan (strenght) yang dimiliki organisasi berikut potensi sumber daya keuangan yang mungkin dapat diserap, dengan jumlah kebutuhan keuangan yang diproyeksikan, perkiraan pemasukan keuangan organisasi harus diproyeksikan bersama dengan perkiraan anggaran belanja organisasi baik dalam masing-masing satuan 1 (satu) tahun anggaran maupun dalam satu periode kepengurusan Karang Taruna yang bersangkutan.

\section{Pengelolaan Keuangan Organisasi Karang Taruna \\ Pengelolaan keuangan organisasi Karang Taruna berarti setiap} penyelenggaraan kegiatan administrasi keuangan yang timbul akibat adanya transaksi penerimaan/ pendapatan keuangan dan pembelanjaannya agar dapat menjadi bahan pemeriksaan yang akurat dan pertanggungjawaban yang accountable. Prinsip-prinsip pengelolaan keuangan Karang Taruna sebgai berikut:

1) Pengelolaan keuangan organisasi diselenggarakan oleh seorang bendahara organisasi yang bertindak selaku akuntan dan kasir organisasi; 


\section{JURNAL ABDIMAS

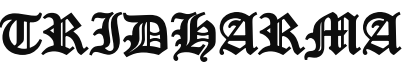 AIA}

2) Pengelolaan keuangan organisasi Karang Taruna diselenggarakan dalam sebuah pembukuan yang sederhana dan standar yang terdiri:

a) Buku Jurnal, yang memuat pencatatan tentang penerimaan dan pengeluaran keuangan yang diselenggarakan secara harian;

b) Neraca Keuangan, yang memuat kondisi keuangan berimbang antara penerimaan dan pengeluaran keuangan organisasi dan dibuat setiap bulan sekali;

c) Buku Kas, yang memuat pencatatan tentang kondisi kas organisasi baik yang tunai ditangan (petty cash) maupun yang tersimpan dalam tabungan dan/atau deposito.

3) Pada prinsipnya setiap penerimaan (pemasukan) dan pengeluaran keuangan organisasi Karang Taruna adalah suatu transaksi yang harus dibuktikan dengan bukti penerimaan/pengeluaran dalam bentuk kuitansi;

4) Kuitansi seperti dimaksud dalam ayat 3 pasal ini selain diketahui oleh pembuat transaksi juga harus diketahui oleh bendaharawan organisasi dalam bentuk pembubuhan paraf dan stempel organisasi;

5) Setiap transaksi penerimaan dan pengeluaran keuangan organisasi harus dibukukan dalam buku jurnal keuangan organisasi oleh bendaharawan organisasi sesuai dengan tanggal dan tempat transaksi;

6) Bendaharawan organisasi dapat memenuhi permintaan pengeluaran keuangan organisasi untuk keperluan rutin organisasi maupun keperluan pelaksanaan program kerja organisasi, setelah mendapat persetujuan dari Ketua/Ketua Umum sebagai pemegang otoritas keuangan organisasi tertinggi;

7) Setiap permintaan pengeluaran keuangan organisasi Karang Taruna harus disertai persyaratan sebagai berikut:
a) Proposal kegiatan yang bersangkutan, untuk permintaan

pengeluaran keuangan organisasi bagi pelaksanaan program kegiatan tertentu;

b) Uraian prakiraan anggaran yang dibutuhkan;

c) Mengisi formulir permintaan pengeluaran keuangan organisasi (Cash Advance).

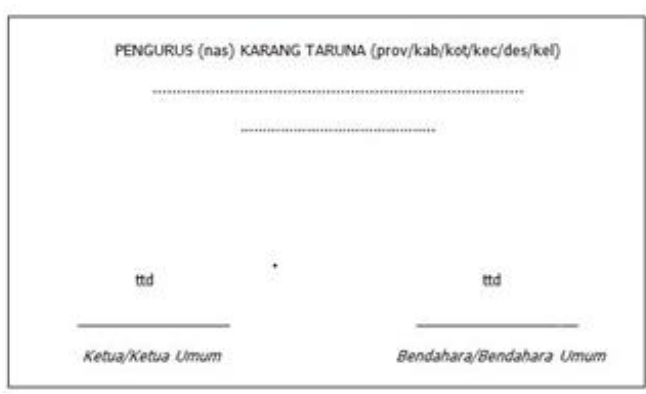

Gambar 2.3 Tampak Belakang Kartu Iuran Anggota

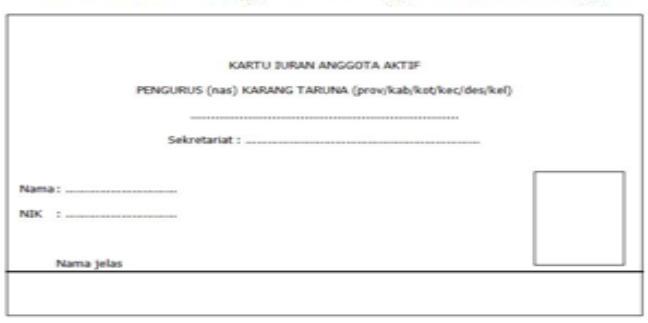

Gambar 2.1 Tampak Depan Kartu Iuran Anggota

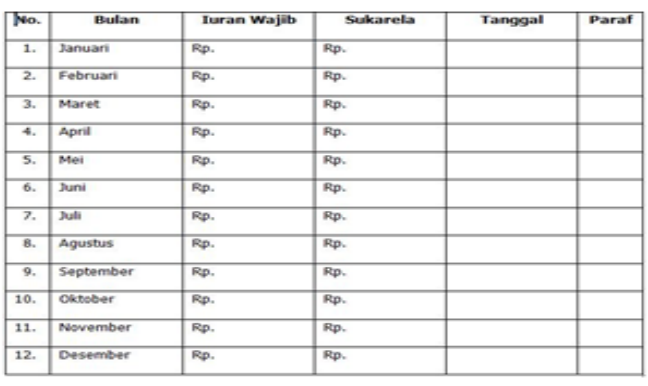

Gambar 2.2 Tampak Tengah Kartu Iuran Anggota

\section{Laporan Pengeluaran Keuangan Karang Taruna}

Pengeluaran keuangan organisasi yang disetujui harus dilaporkan kepada Bendaharawan organisasi oleh yang mengajukan permintaan pengeluaran keuangan organisasi dengan ketentuan sebagai berikut:

1) Pengeluaran keuangan organisasi untuk keperluan rutin langsung dilaporkan kepada bendaharawan organisasi dalam 


\section{JURNAL ABDIMAS

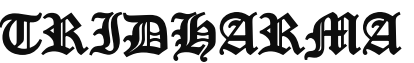 AtA}

jangka waktu selambat-lambatnya 1 (satu) minggu setelah penggunaan;

2) Pengeluaran keuangan organisasi untuk keperluan pelaksanaan program kegiatan (kepanitian tertentu), laporan dikelola secara internal oleh bendaharawan panitia/tim kerja yang bersangkutan dengan jangka waktu selambat-lambatnya 1(satu) minggu setelah penggunaan, kemudian panitia melalui bendaharanya akan melaporkan kepada bendaharawan organisasi bersamaan dengan laporan akhir panitia/timkerja tetentu dalam jangka waktu selambat-lambatnya 1 (satu) bulan setelah pelaksanaan program kegiatan yang bersangkutan;

3) Laporan penggunaan keuangan organisasi harus berisikan uraian penggunaan, tanggal transaksi, dan bukti kuitansi.

\section{Pandemi Covid-19}

Coronavirus Disease 2019 (COVID19) adalah penyakit menular yang disebabkan oleh Severe Acute Respiratory Syndrome Coronavirus 2 (SARS-CoV-2). SARS-CoV-2 merupakan coronavirus jenis baru yang belum pernah diidentifikasi sebelumnya pada manusia (KemenKes, 2020). Ada setidaknya dua jenis coronavirus yang diketahui menyebabkan penyakit yang dapat menimbulkan gejala berat seperti Middle East Respiratory Syndrome (MERS) dan Severe Acute Respiratory Syndrome (SARS). Tanda dan gejala umum infeksi COVID-19 antara lain gejala gangguan pernapasan akut seperti demam, batuk dan sesak napas. Masa inkubasi rata- rata 5-6 hari dengan masa inkubasi terpanjang 14 hari. Pada kasus COVID- 19 yang berat dapat menyebabkan pneumonia, sindrom pernapasan akut, gagal ginjal, dan bahkan kematian.

Indonesia melaporkan kasus pertama pada tanggal 2 Maret 2020. Kasus meningkat dan menyebar dengan cepat di seluruh wilayah Indonesia. Sampai dengan tanggal 3 Novemer 2020 Kementerian Kesehatan melaporkan 418.375 kasus konfirmasi COVID-19 dengan 14.146 kasus meninggal. Dilihat dari situasi penyebaran COVID-19 yang sudah hampir menjangkau seluruh wilayah provinsi di Indonesia dengan jumlah kasus dan/atau jumlah kematian semakin meningkat dan berdampak pada aspek politik, ekonomi, sosial, budaya, pertahanan dan keamanan, serta kesejahteraan masyarakat di Indonesia, Pemerintah Indonesia telah menetapkan Keputusan Presiden Nomor 11 Tahun 2020 tentang Penetapan Kedaruratan Kesehatan Masyarakat Corona Virus Disease 2019 (COVID-19).

Sampai saat ini, situasi COVID-19 di tingkat global maupun nasional masih dalam risiko sangat tinggi. Selama pengembangan vaksin masih dalam proses, dunia dihadapkan pada kenyataan untuk mempersiapkan diri hidup berdampingan dengan COVID-19. Oleh karenanya diperlukan pedoman dalam upaya pencegahan dan pengendalian COVID-19 untuk memberikan panduan bagi petugas kesehatan agar tetap sehat, aman, dan produktif, dan seluruh penduduk Indonesia mendapatkan pelayanan yang sesuai standar. Pedoman pencegahan dan pengendalian COVID-19 disusun berdasarkan rekomendasi WHO yang disesuaikan dengan perkembangan pandemi COVID-19, dan ketentuan peraturan perundangundangan yang berlaku.

\section{Cara Penyebaran Virus Covid-19}

Menurut World Healt Organization (WHO), terdapat empat cara penyebaran Virus Covid- 19 yaitu :

\section{Transmisi Droplet}

Transmisi SARS-CoV-2 dapat terjadi melalui kontak langsung, kontak tidak langsung, atau kontak erat dengan orang yang terinfeksi melalui sekresi seperti air liur dan sekresi saluran pernapasan atau droplet saluran napas yang keluar saat orang yang terinfeksi batuk, bersin, berbicara, atau menyanyi, droplet saluran napas yang mengandung virus dapat mencapai mulut, hidung, mata orang yang rentan dan dapat menimbulkan infeksi. Transmisi kontak tidak langsung di mana terjadi kontak 


\section{JURNAL ABDIMAS

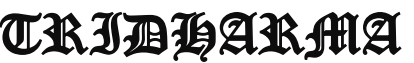 AIA:}

antara inang yang rentan dengan benda atau permukaan yang terkontaminasi (transmisi fomit) juga dapat terjadi.

2. Transmisi Udara

Transmisi melalui udara didefinisikan sebagai penyebaran agen infeksius yang diakibatkan oleh penyebaran droplet nuclei (aerosol) yang tetap infeksius saat melayang di udara dan bergerak hingga jarak yang jauh. Transmisi SARS-CoV2 melalui udara dapat terjadi selama pelaksanaan prosedur medis yang menghasilkan aerosol ("prosedur yang menghasilkan aerosol"). WHO, bersama dengan kalangan ilmuwan, terus secara aktif mendiskusikan dan mengevaluasi apakah SARS-CoV-2 juga dapat menyebar melalui aerosol, di mana prosedur yang menghasilkan aerosol tidak dilakukan terutama di tempat dalam ruangan dengan ventilasi yang buruk (Asadi, 2019)

\section{Transmisi Formit}

Sekresi saluran pernapasan atau droplet yang dikeluarkan oleh orang yang terinfeksi dapat mengontaminasi permukaan dan benda, sehingga terbentuk fomit (permukaan yang terkontaminasi). Virus dan/atau SARSCoV-2 yang hidup dan terdeteksi melalui RTPCR dapat ditemui di permukaan- permukaan tersebut selama berjam-jam hingga berhari-hari, tergantung lingkungan sekitarnya (termasuk suhu dan kelembapan) dan jenis permukaan. Karena itu, transmisi juga dapat terjadi secara tidak langsung melalui lingkungan sekitar atau bendabenda yang terkontaminasi virus dari orang yang terinfeksi (misalnya, stetoskop atau termometer), yang dilanjutkan dengan sentuhan pada mulut, hidung, atau mata.

4. Transmisi Lainnya

Bukti sampai saat ini menunjukkan bahwa SARS-CoV-2 paling miripdengan betacoronavirus pada kelelawar yang diketahui; peran inang perantara dalam memfasilitasi transmisi pada kasus-kasus manusia paling awal yang diketahui masih belum jelas. Selain penelitian tentang kemungkinan inang(inang) perantara SARS-CoV-2, sejumlah penelitian sedang dilakukan untuk lebih memahami kerentanan mamalia, termasuk anjing, kucing dan cerpelai ternak. Namun, masih belum jelas apakah mamalia-mamalia ini jika terinfeksi memberikan risiko transmisi ke manusia yang signifikan.

\section{METODE PELAKSANAAN}

Metode pelaksanaan kegiatan merupakan cara pelaksanaan yang menjelaskan secara singkat tata cara pelaksanaan program, adapun metode tersebut disajikan dalam bagan dibawah ini:

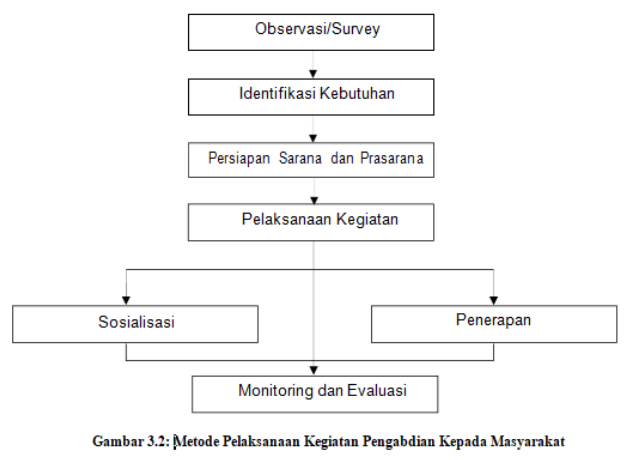

Secara lengkap metode pelaksanaan kegiatan akan disajikan secara lengkap melalui penjelasan dibawah ini,

a. Survei Tempat Pelaksanaan KegiatanKegiatan ini dimaksudkan untuk menggali informasi tentang kondisi geografis dan kondisi masyarakat didaerah tempat kegiatan. Informasi tersebut berupa lokasi, permasalahan yang dihadapi dalam pada lokasi tersebut.

b. Persiapan Sarana dan Prasarana

Kegiatan ini dimaksudkan untuk merencanakan kebutuhan baik sarana dan prasarana yang akan digunakan dalam pelaksanaan kegiatan dengan tetap memperhatikan kebutuhan masyarakat secara umum dan khusus demi tercapainya target pengabdian kepada masyarakat. Sarana dan prasarana yang dimaksud berupa projektor, spanduk dan lain-lain.

c. Pelaksanaan Kegiatan 


\section{JURNAL ABDIMAS

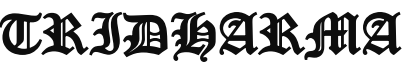

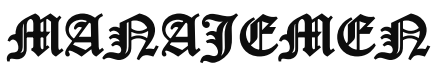

Setelah melakukan survey dan persiapan sarana dan prasarana maka pelaksanaan kegiatan dilaksanakan oleh pengusul besrta anggota dan beberapa mahasiswa. Kegiatan yang dilakukan adalah berupa penyuluhan dalam bentuk pertemuan secara langsung dan ormbagian sembako yang bertempat di Karang Taruna 022, Jalan Pondok Salak RT.005/RW.022, Kelurahan Pondok Benda, Kecamatan Pamulang Kota Tangerang Selatan yang menitikberatkan pada Penyuluhan peran organisasi Karang Taruna dalam pelaihan peningkatan kesehatan dan perencanaan keuangan di masa pandemi.

d. Monitoring dan Evaluasi

Kegiatan ini dimaksudkan untuk meninjau perkembangan aktualisasi masyarakat terhadap kegiatan yang telah dilakukan sebelumnya dengan harapan dapat dilaksanakan sesuai dengan teori yang telahdi peroleh melalui kegiatan yang telah dilaksanakan. Evaluasi juga bertujuan untuk memahami pola pemahaman masyarakat terhadap informasi baru yang diperoleh dari pelaksana kegiatan. Hasil ini diharapkan mampu menjadi dasar Sosialisasi terhadap Pemakaian masker dan hand sanitizer guna memutus mata rantai di lingkungan Rumah pintar dan masyarakat sekitarnya.

\section{HASIL DAN PEMBAHASAN \\ Hasil Kegiatan}

Kegiatan sosialisasi dan penerapan di Karang Taruna 022 tentang Penyuluhan Peran Organisasi Karang Taruna Dalam Pelatihan Peningkatan Kesehatan Dan Perencanaan Keuangan Di Masa Pandemi Jalan Pondok Salak RT.005/RW.022, Kelurahan Pondok Benda, Kecamatan Pamulang Kota Tangerang Selatan yang berjumlah 12 peserta.

Kegiatan penyuluhan dan pembinaa ini dimulai dengan sambutan dari ketua pelaksana dan dari pihak Karang Taruna 022 yaitu selanjutnya perkenalan anggota pengabdian kepada masyarakat dan juga para anggota Karang Taruna 022 di RW.022 Kelurahan Benda Baru tujuannya untuk membuat suasana lebih akrab. Setelah itu, pemateri menayangkan slide power point yang berkaitan dengan materi Penyuluhan Peran Organisasi Karang Taruna Dalam Pelatihan Peningkatan Kesehatan Dan Perencanaan Keuangan Di Masa Pandemi. Respon dari Karang Taruna 022 itu sendiri sangat baik. Terlihat ketika pemateri menanyakan Penerapan dan Penyuluhan Peran Organisasi Karang Taruna Dalam Pelatihan Peningkatan Kesehatan Dan Perencanaan Keuangan Di Masa Pandemi ke salah satu anggota Karang Taruna 022 respon yang diberikan cepat menangkap dan dengan mudah menerima pengetahuan dari materi tersebut.

Alhamdulillah kegiatan sosialisasi dan cara pemakaian masker dan hand sanitizer yang baik dan benar guna memutus mata rantai covid- 19 berjalan cukup baik, karena semua peserta sangat merespon dengan baik dalam kegiatan ini. Berdasarkan wawancara, tanya jawab dalam kegiatan tersebut ada beberapa perubahan yang dilihat dari para anggota rumah pintar yang mengikuti kegiatan sosialisasi dan cara pemakaian masker dan hand sanitizer yang baik dan benar sebagai upaya pencegahan penyebaran virus covid -19 sebagai bentuk pelatihan peningkatan kesehatan dan perencanaan keuangan. Dengan pengamatan langsung selama kegiatan berlangsung, kegiatan pengabdian pada masyarakat ini memberikan hasil sebagai berikut :

1. Meningkatkan pengetahuan dan kemampuan individu agar mau dan mampu mengambil tindakan yang dapat meningkatkan dan memelihara kesehatannya.

2. Menyiapkan akses terhadap sarana yang diperlukan untuk praktik Pemakaian dan Hand Sanitizer baik di tempat tinggal maupun di lingkungan sekitar, sekolah, dan lingkungan kerja.

3. Mengidentifikasi kebiasaan keluarga dan masyarakat yang menghalangi mereka agar selalu memakai masker dan menggunkan hand sanitizer agar memutus upaya penyebaran covid-19 


\section{JURNAL ABDIMAS

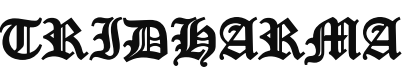



dan selalu berperilaku hidup bersih dan sehat.

4. Merubah pandangan tentang Pemakaian Masker dan Hand sanitizer yan baik dan benar dengan melibatkan berbagai tokoh di masyarakat.

5. Menyediakan informasi tentang praktik-praktik perencanaan keuangan yang baik dan benar.

\section{Faktor Pendukung dan Faktor Penghambat}

Beberapa faktor yang mendukung terlaksananya kegiatan pengabdian pada masyarakat ini adalah besarnya minat dan antusiasme peserta selama kegiatan, sehingga kegiatan berlangsung dengan lancar dan efektif, Secara langsung Mensosialisasikan cara pemakaian masker dan hand sanitizer yang baik dan benar Sedangkan faktor penghambatnya adalah keterbatasan waktu sosialisasi dan penerapannya karena hanya memakai waktu yang singkat dan tidak terlalu lama dan juga social distancing.

\section{Pembahasan}

Untuk melaksanakan kegiatan PKM ini digunakan beberapa metode penyuluhan yaitu sebagai berikut :

a. Metode Ceramah $\rightarrow$ Metode yang digunakan dalam penyuluhan ini yaitu penyuluhan dengan memberikan ceramah atau presentasi dengan tema "Penyuluhan Peran Organisasi Karang Taruna Dalam Pelatihan Peningkatan Kesehatan Dan Perencanaan Keuangan Di Masa Pandemi"

b. Metode Diskusi Dan Tanya Jawab $\rightarrow$ Setelah sesi pemberian materi selesai, maka dilanjutkan dengan sesi diskusi dengan tanya jawab. Hasil yang didapatkan anggota Karang Taruna sangat antusias untuk bertanya terkait bagaimana cara untuk peningkatan kesehatan dan perencanaan keuangan di masa pandemi. Untuk peserta yang aktif dan berani bertanya kami berikan reward berupa cinderamata dari
Universitas Pamulang dan sumbangsih dari dosen-dosen Universitas Pamulang.

c. Metode Simulasi $\rightarrow$ Penyuluhan ini juga menggunakan metode simulasi, sehingga peserta langsung dapat mempraktekan apa yang sudah disampaikan. Apabila ada kendala yang dirasakan maka langsung dibantu pada saat pelaksanaan PKM. Simulasi ini penting dilakukan untuk mengetahui seberapa besar tingkat pengetahuan dan ilmu yang diserap oleh anggota Karang Taruna selama penyuluhan.
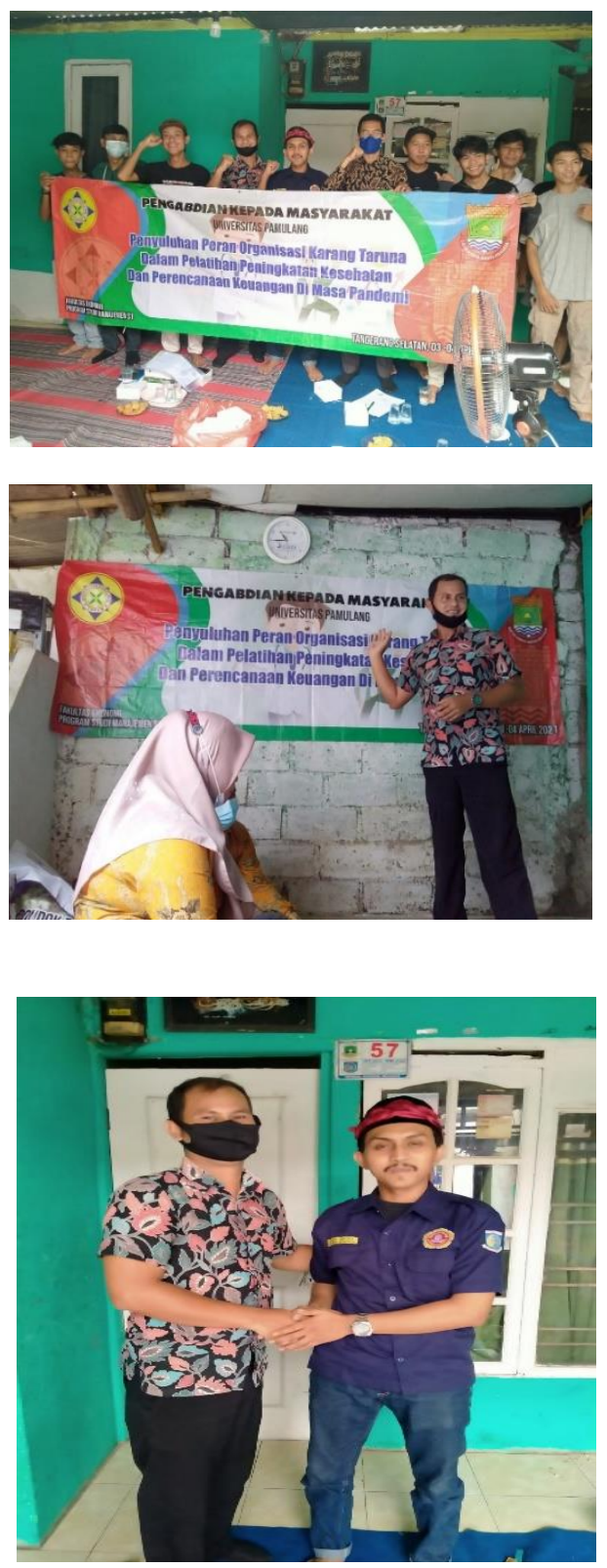


\section{JURNAL ABDIMAS

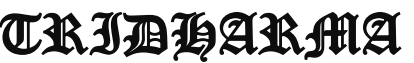 \\ AtA:}

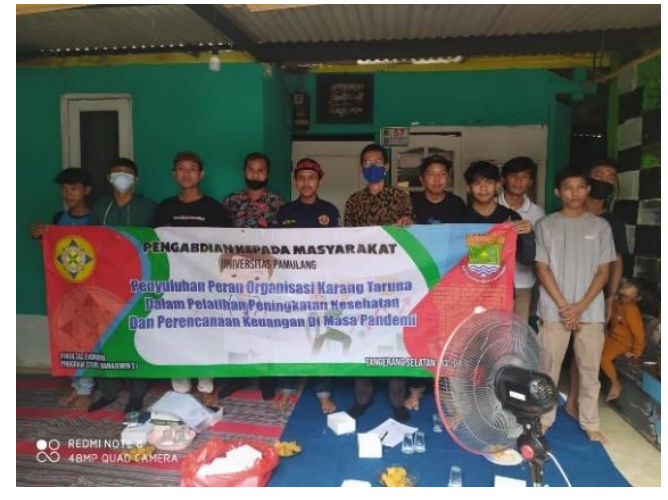

\section{KESIMPULAN DAN SARAN \\ Kesimpulan}

Pelaksanaan kegiatan Pengabdian Kepada Masyarakat oleh Lembaga Penelitian dan Pengabdian Masyarakat (LPPM) Universitas Pamulang yang dilakukan oleh dosen-dosen program studi Manajemen telah berjalan dengan lancar dan mendapat sambutan hangat dari tempat pelaksanaan kegiatan ini yaitu dilakukan pada Karang Taruna 022 Jalan Pondok Salak RT.005/RW.022, Kelurahan Pondok Benda, Kecamatan Pamulang Kota Tangerang Selatan, yang berjumlah 12 peserta.

Harapan kami dengan pengabdian ini dapat membuka wawasan dari pada Karang Taruna 022 Jalan Pondok Salak RT.005/RW.022, Kelurahan Pondok Benda, Kecamatan Pamulang Kota Tangerang Selatan Sebagai Upaya Pencegahan Penyebaran Virus Covid-19 dan mengelola keuangannya di masa pandemi. Materi yang kami berikan yaitu Penyuluhan Peran Organisasi Karang Taruna Dalam Pelatihan Peningkatan Kesehatan Dan Perencanaan Keuangan Di Masa Pandemi.

Tata cara Dan Penyuluhan Peran Organisasi Karang Taruna Dalam Pelatihan Peningkatan Kesehatan Dan Perencanaan Keuangan Di Masa Pandemi yang baik dan benar ini adalah untuk bisa dan belajar agar para anggota dan pengurus Karang Taruna maupun masyarakat agar peduli dan mengutamakan kesehatan untuk mewujudkan kehidupan yang lebih berkualitas. Pemakaian masker dan hand sanitizer harus dipraktikkan secara terus menerus agar menjadi suatu pola kebiasaan, Keterlibatan seluruh anggota keluarga akan menciptakan suasana yang mendukung bagi terbentuknya pola perilaku hidup baik dan benar. Anakanak lebih berpotensi meniru perilaku orang dewasa, daripada melakukan perintah (suara) ataupun instruksi dari orang dewasa. Orang dewasa harus mempraktikkan cara pemakaian masker dan hand sanitizer yang baik dan benar secara terus-menerus (konsisten) dan benar baik saat di rumah maupun di luar rumah. Dengan begitu, akan tercipta pola dan tatanan yang teratur guna memutus mata rantai covid-19.

Hal-hal penting untuk dalam Pelatihan Peningkatan Kesehatan Dan Perencanaan Keuangan Di Masa Pandemi di Karang Taruna 022 baik di lingkungan keluarga dan masyarakat:

1. Meningkatkan pengetahuan dan kemampuan individu agar mau dan mampu mengambil tindakan yang dapat meningkatkan dan memelihara kesehatannya.

2. Menyiapkan akses terhadap sarana yang diperlukan untuk praktik dan Sosialisasi Pemakaian Masker dan Hand Sanitizer baik di tempat tinggal maupun di lingkungan sekitar, sekolah, dan lingkungan kerja.

3. Mengidentifikasi kebiasaan keluarga dan masyarakat yang menghalangi mereka dalam mempraktikkan pemakaian masker dan hand sanitizer yang baik dan benar.

4. Merubah pandangan tentang peningkatan kesehatan yang baik dan benar dengan melibatkan berbagai tokoh di masyarakat.

5. Menyediakan informasi tentang praktik-praktik perencanaan keuangan yang tepat.

Terkait dengan pencegahan penyebaran Virus CORONA (COVID19), patuhilah semua anjuran pemerintah untuk menjaga kesehatan, 


\section{JURNAL ABDIMAS

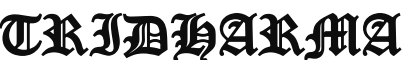

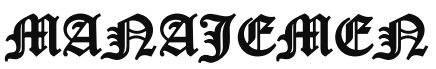

\section{P-ISSN 2615-6849, E-ISSN 2716-070X}

Jurnal ABDIMAS Vol. 2,No.3, Agustus 2021,Hal(62-74)

@ Prodi Manajemen Fakultas Ekonomi Universitas Pamulang

Email: abdimasjurnal.unpam@ gmail.com Telp: (021) 741-2566 melalui: Mengurangi Risiko dengan mencuci dengan sabun dan air yang mengalir, kurangi Kontak Langsung (Physical Distancing), dan menjaga Kesehatan Fisik dan Mental.

\section{Saran}

Mengingat besarnya manfaat kegiatan pengabdian pada masyarakat ini, maka selanjutnya perlu:

1) Mengadakan penyuluhan dan pembinaan serupa pada rumah pintah lainnya ataupun pada masyarakat siswa sekolah lain dengan materi yang sama.

2) Adanya kesinambungan program pasca kegiatan pengabdian ini sehingga masyarakat benar-benar dapat termotivasi untuk mempraktikkan perilaku hidup bersih dan sehat.

3) Untuk Masyarakat: Bisa memakai Masker dan Hand Sanitizer yang baik dan benar karena selama ini masyarakat banyak yang belum bisa memakai masker dan hand sanitizer yang tepat, agar dapat meningkatkan perilaku hidup bersih dan sehat yang baik, Melakukan pemantauan berkala pada lingkungan masyarakat, agar berperilaku bersih dan sehat dengan mengurangi risiko dengan mencuci dengan sabun dan air yang mengalir, kurangi Kontak Langsung (Physical Distancing).

4) Merencanakan keuangan dengan baik agar senantiasa dan mengelola dan menggunakan uang dengan bijak.

\section{DAFTAR PUSTAKA}

1. Asadi S, Wexler AS, Cappa CD, Barreda S, Bouvier NM, Ristenpart WD. Aerosol emission and superemission during human speech increase with voice loudness. Sci Rep. 2019;9:2348
2. Berger, Peter L., dan Thomas Luckman. 1990. Tafsir Sosial dan Kenyataan. Jakarta: LP3ES.

3. Dessler, Gary. 2008. Manajemen Sumber Daya Manusia . Terj. Edisi kesepuluh jilid I bekerja sama dengan Paramita Rahayu. Indonesia: PT Macanan Jaya Cemerlang.

4. https://tirto.id/protokol-new-normalkemenkes-untuk-cegah-penularancorona- covid-19-fCRj

5. https://www.karangtaruna.id/p/sistem-manajemenkeuangan-karang-taruna.html

6. Kemenkes RI (2011). Peraturan Menteri Kesehatan No. 2269/ MENKES/PER/XI/2011 Tentang Pedoman Perilaku Hidup Bersih Dan Sehat. Jakarta.

7. Kementerian Kesehatan RI (2020). PEDOMAN PENCEGAHAN DAN PENGENDALIAN CORONAVIRUS DISESASE (COVID-19)

8. Mac Iver, R. M. \& Charles H. 1961. Society An Introducing Analysis. London : Macmilan \& co ltd.

9. Mondy, R. Wayne. 2008. Manajemen Sumber Daya Manusia. Terj. Edisi kesepuluh jilid I bekerja sama dengan Penerbit Erlangga. Jakarta: Erlangga.

10. Notoatmodjo, Soekidjo. Pendidikan dan Perilaku Kesehatan. Jakarta. Rineka Cipta. 2003.h. 3.

11. Proverawati, A., \& Rahmawati, E. (2012). Perilaku hidup bersih dan sehat. Yogyakarta. Nuha Medika.

12. Stadnytskyi V, Bax CE, Bax A, Anfinrud P. The airborne lifetime of small speech droplets and their potential importance in SARS-CoV-2 transmission. Proc Ntl Acad Sci. 2020;117:11875-7.

13. WHO (2020). Penyataan Keilmuan : Transmisi SARS-CoV-2: implikasi terhadap kewaspadaan pencegahan infeksi.

14. Oktrima, B., Tumanggor, M., sari Budhiarjo, I., Akbar, A. R., \& Darsita, I. (2021). MENINGKATKAN PERAN IBU RUMAH TANGGA DALAM 
JURNAL ABDIMAS

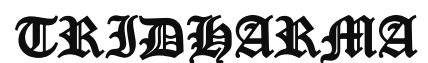

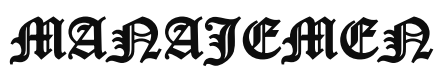

P-ISSN 2615-6849, E-ISSN 2716-070X

Jurnal ABDIMAS Vol. 2,No.3, Agustus 2021,Hal(62-74)

@ Prodi Manajemen Fakultas Ekonomi Universitas Pamulang

Email: abdimasjurnal.unpam@ gmail.com Telp: (021) 741-2566
KEUANGAN DI KELURAHAN PONDOK BENDA TANGERANG SELATAN. Jurnal Abdimas Tri Dharma Manajemen, 2(1), 1-8.

15. Mardiana, S., Supriyatna, W., Zakaria, Z., Dumilah, R., \& Budhiarjo, I. S. (2020). Sosialisasi dan Penyuluhan Tentang Pentingnya Menabung Bagi Generasi Muda Khususnya Siswa Madrasah Tsanawiyah Mts Mathlaul Anwar Pamulang. DEDIKASI PKM, I(2), 79-86.

16. Budhiarjo, I. S., Irnawati, J., \& Mulyani, S. (2020). Pengembangan Kualitas Sumber Daya Manusia dalam Lembaga Keuangan (Perbankan Syariah). DEDIKASI PKM, 1(2), 8792.

17. Pasaribu, V. L. D., Agrasadya, A., Shabrina, N., \& Krisnaldy, K. (2020). Menjadi Enterpreneur Muda Yang Memiliki Jiwa Leadership Untuk Menghadapi Masa Depan. Abdi Laksana: Jurnal Pengabdian Kepada Masyarakat, 1(1).

18. Pasaribu, V. L. D., Sulaiman, S., Sutiman, S., Thaharudin, T., \& Purnomo, B. Y. (2020). Pengenalan Letak Posyandu Terdekat Dikelurahan Pisangan Dengan Manajemen Pemasaran Revolusi 4.0 Untuk Meningkatkan Pengetahuan Masyarakat Letak Dan Fungsi Posyandu Terdekat Pada Kelurahan Pisangan. Dedikasi Pkm, 1(1), 105110.

19. Pasaribu, V. L. D., Oktrima, B., Prabowo, B., Arianto, N., \& Haryoko, U. B. (2020). Progam Pendampingan Dan Penyelenggaraan Pendidikan Anak Pada Usia Dini Terhadap Prestasi Belajar Dilingkungan Rt 020 Rw 009. Kel Giri Peni. Kec Wates. Yogyakarta. Jurnal Lokabmas Kreatif, 1(1), 71-75.
20. Pasaribu, V. L. D., Jannah, M., Fazar, M., Putra, S. P., Monalisa, M., \& Sofa, M. (2021). MENINGKATKAN PRODUKTIVITAS USAHA DIMASA PANDEMI PADA IBU PKK RT 004/003 KELURAHAN SAWAH BARU CIPUTAT, TANGERANG SELATAN. Abdi Laksana: Jurnal Pengabdian Kepada Masyarakat, 2(2), 295-301.

21. Pasaribu, V. L. D., Yuniati, H. L., Pranata, R., Sembayu, R., Purba, S. M., \& Nurbayani, T. T. A. (2021). MANAJEMEN KEUANGAN UNTUK MENGHADAPI DAN BERTAHAN DI ERA COVID 19. Jurnal Abdimas Tri Dharma Manajemen, 2(2), 12-18.

22. Pasaribu, V. L. D., Syafei, A. N., Farhan, A., Aufaizah, A., Irani, C., \& Firtiayani, S. R. (2021). PENGARUH DISPLIN PROTOKOL KESEHATAN TERHADAP PENCEGAHAN PENULARAN VIRUS COVID19. Jurnal Abdimas Tri Dharma Manajemen, 2(2), 91-98.

23. Pasaribu, V. L. D., Septiani, F., Rahayu, S., Lismiatun, L., Arief, M., Juanda, A., ... \& Rahim, R. (2021). Forecast Analysis of Gross Regional Domestic Product based on the Linear Regression Algorithm Technique.

24. Priadi, A., Pasaribu, V. L. D., Virby, S., Sairin, S., \& Wardani, W. G. (2020). Penguatan Ekonomi Kreatif Berbasis Sumber Daya Desa Dikelurahan Rempoa. Abdi Laksana: Jurnal Pengabdian Kepada Masyarakat, 1(3), 356-35 